\title{
Legal Basis of Free Legal Aid State System Administration in the Russian Federation
}

\author{
Andrei Y. Aleksandrov ${ }^{1}$, Svetlana V. Barabanova ${ }^{2}$, Svetlana B. Vereshchak ${ }^{1}$, Olga A. Ivanova ${ }^{1} \&$ Zhanna A. $^{2}$ \\ Aleksandrova $^{1}$ \\ ${ }^{1}$ I. N. Ulyanov Chuvash State University, Cheboksary, Russia \\ ${ }^{2}$ Kazan National Research Technological University, Kazan, Russia \\ Correspondence: Andrei Y. Aleksandrov, Professor of I.N. Ulyanov Chuvash State University, 428000, \\ Moskovsky Prospect, 15, Cheboksary, Russia. E-mail: public_law@mail.ru
}

Received: May 7, 2015 Accepted: May 16, 2015 Online Published: May 28, 2015

doi:10.5539/jsd.v8n3p277 URL: http://dx.doi.org/10.5539/jsd.v8n3p277

\begin{abstract}
The urgency of the problem under investigation is determined by the fact that at times of the global financial crisis, coupled with the economic slowdown in the Russian Federation, there is a need to improve the management of legal aid state system aimed at improving the social protection of low-income citizens, ensuring their access to justice. The article aims to make recommendations on improving the efficiency of public administration of the state system of free legal aid. The leading approach to the study of this problem is to analyze the experience of organizations of free legal assistance in the Russian Federation (on the example of the Volga Federal District), aimed at identifying the strengths and weaknesses of the system, processing statistical data on applications for its provision and its effectiveness for those who seek it, identifying the contingent of those who applied and determining the effectiveness of the interaction of government institutions and non-governmental organizations in the provision of such assistance. As a result of the research conclusions are drawn about the need to improve the quality level of cooperation between different authorities within the public administration in order to avoid the bureaucratization of procedures for free legal aid, to encourage the mobility of members of the legal state aid, to improve the quality of free legal aid, expanding the list of services provided within it, to actively involve local authorities in the provision of free legal aid as a way of implementing the principle of free and specific access to it. The article may be useful in a practical way for government agencies, local authorities, representatives of the legal community and other participants in the system of free legal aid, as well as for scientific and teaching staff for further research concerning the provision of free legal assistance in accordance with national and international experience.
\end{abstract}

Keywords: constitutional right on access to justice, a free legal aid, public administration, low-income citizens

\section{Introduction}

One of the fundamental constitutional guarantees in the system of the legal status of a person is the right to qualified legal assistance, including free legal aid in cases prescribed by law. This right is enshrined and guaranteed by paragraph 1 of Article 48 of the Constitution of the Russian Federation. At the federal level, the legal relations are regulated by the Federal Law of 21.11.2011 № 324-FL "On free legal aid in the Russian Federation" (hereinafter - the Federal Law № 324-FL) entered into force on 15.01.2012. This law establishes the basic guarantees of the rights of Russian citizens to receive qualified free legal assistance, organizational and legal basis for the formation of state and non-state systems of free legal assistance and activities for legal awareness and legal education of the population, the sources and methods of funding. This free legal aid is a guarantee of the constitutional principle of equality of rights and freedoms, inter alia before the law, enshrined in Article 19 of the Constitution of the Russian Federation. (Konin, 2013) Therefore, securing the constitutional right to qualified legal assistance free of charge in cases specified by law, the state provides the persons, who do not have sufficient means to pay for it, with equal opportunities to those individuals who can pay for the services of a specialist.

Implementation of the above mentioned constitutional guarantee in the Russian Federation is carried out by governmental and non-governmental organizations, providing legal assistance and support of people -recipients of free legal aid (Vereshchak, 2014). There is no doubt that the free legal aid governmental system is the most 
stable, secure, and is, consequently, in demand with low-income citizens (Panchenko, 2012). Creating efficient free legal aid system management will largely stipulate for the quality of its implementation, free access of those who need it, strengthening the governmental authority and the population's trust to it.

It is noteworthy that the free legal aid institution has been known since the times of ancient states until modern times. If a state made a decision to abandon free legal aid, it was short-term, had a negative public response and was invariably restored within a short period of time (Ivanova, 2014). Regulatory framework of the legal state aid system is the Constitution of the Russian Federation, Federal Law of 21.11.2011 № 324-FZ "On free legal aid in the Russian Federation" (as amended) (hereinafter - the Law on free legal aid), the Federal Act of May 2, 2006 № 59-FZ "On the procedure of the Russian Federation citizens' addresses consideration " (as amended), the Federal Law of May 31, 2002 № 63-FZ "On Advocacy and Legal Practice" (as amended), the Federal Act of August 2, 1995 № 122-FZ "On social services for the elderly and disabled persons" (as amended), the laws and regulations of the legislative (representative) and executive power, determining the list of public authorities, who are responsible for providing free legal aid on the territory of the Russian Federation.

Adoption of the Federal law № 324-FZ demanded from subjects of the Russian Federation formation of absolutely new regional regulatory base in this field. Frame character of the Federal law № 324-FZ assumes existence of the legislation of subjects of the Russian Federation considering regional specifics in this area. Subjects of the Russian Federation have the right to independently determine the range of governmental bodies included in the free legal aid state system that entails a variety of options to manage the system. The Volga Federal District unites the subjects of the Russian Federation uniform in an orientation of mentality of the population but different in a standard of living, number and population density, the organization of a financial system (existence not subsidized and subsidized regions).The free legal aid state system in different regions of the Russian Federation is represented by different government bodies and agencies, as well as a variety of methods to reimburse free legal aid expenses to non-governmental agencies (Alexandrov, 2014). An example of the Volga Federal District demonstrates considerable diversity that is characteristic for other regions of the Russian Federation. According to the Reference materials for the meeting of the Coordination Board of the Main Department for Justice of the Russian Federation in Nizhny Novgorod region "On the implementation of the Federal Law of 21.11.2011 № 324-FZ "On free legal aid in the Russian Federation" in the Volga Federal District subjects of the Russian Federation: Problems and Solutions" in the list of free legal aid state system participants in the Nizhny Novgorod region includes the executive authorities of the Nizhny Novgorod region and their subordinate agencies, the Legislative Assembly of the Nizhny Novgorod region, Nizhny Novgorod region government bodies, bodies of territorial control of Mandatory Health Insurance Fund, public law offices, lawyers, providing free legal aid, notaries and other participants. In some subjects - the Chuvash Republic, Penza, Ulyanovsk and Orenburg regions - an exhaustive list of the free legal aid state system participants is approved by regulations (governments, other bodies of executive power). Thus, in the Chuvash Republic, the free legal aid state system includes 20 executive bodies of the Chuvash Republic, 29 budgetary institutions (social service centers, Youth Initiative Centre), 13 state-owned institutions (social rehabilitation centers for minors, for persons of no fixed abode), 1 autonomous institution (National Centre for Protection of Labour). In Penza and Ulyanovsk regions the free legal aid state system includes multifunctional centers providing state and municipal services, in the republics of Bashkortostan and Tatarstan, Orenburg region - state non-budgetary fund departments.

The variety of subjects of state and non-state free legal aid systems stipulates for special features of governing in this field. Public administration of free legal aid system is implemented at the federal level, the level of subjects of the Russian Federation, as well as at the level of local government (in case of granting them with certain state powers in this field).

This problem is still poorly understood, there is no comprehensive fundamental research on problems of formation and realization of regional and federal legislation on the provision of free legal aid that actualizes this study. Statistical studies, carried out by the executive branch of the federal and regional levels, are not used for theoretical generalization and development of science-based recommendations and suggestions to improve the legislation and gaps in the study area. Making the concept of evidence-based organizational, legal and financial framework of legal aid, taking into account the experience of the Volga Federal District will allow the federal and regional legislator to approximate the legal framework to the needs of citizens of the Russian Federation, providing the unity of legal field. The urgency of the problem under investigation is determined by the fact that at times of the global financial crisis, coupled with the economic slowdown in the Russian Federation, there is a need to improve the management of legal aid state system aimed at improving the social protection of low-income citizens, ensuring their access to justice. 


\section{Methodological Framework}

\subsection{Research Methods}

General and particular scientific methods of cognition constitute the methodological basis for the research.

Revealing assumptions and the general laws of development of the system of providing free legal aid was carried out with the help of scientific methods. The dialectical materialist method of knowledge allows us to consider the implementation of the constitutional right to qualified legal aid in terms of variation thereof, to prove the advantages and disadvantages of different approaches to this issue.

Methods of formal logic: description, comparison, classification, analysis and synthesis can reveal and characterize in detail the legal and financial aspects of the functioning of the institution of legal aid.

The application of these methods of scientific knowledge will allow to study the effectiveness of federal and regional legislation, to identify a number of defects and to make regulatory proposals for their elimination.

The internal structure of the system of free legal aid and its effectiveness, the fixation of historical events related to the development of this system is investigated using particular scientific methods of knowledge: formal and legal, comparative, statistical, functional. The comparative legal method is necessary for the disclosure and comparison of different approaches to the provision of free legal assistance in international legal instruments and the legislation of the Russian Federation.

Legalistic method allows to develop recommendations for improving the conceptual-categorical apparatus in the art knowledge.

The statistical method is to be used to collect and compile information on the number and categories of citizens who applied for free legal aid in the Volga Federal District, the demand for this type of public service, the level of funding and its use in the provision of free legal aid, as well as develop recommendations for improving the legal and financial security institution of legal aid.

By structural and functional method revealed the internal structure of the system of free legal aid, singled out some of its elements is given functional characteristics, analyzes their relationship.

Application of these methods allow to investigate the matter under consideration in the relationship and interdependence, identify certain trends, make generalizations and conclusions.

The study is based on a multidisciplinary approach, in which the issues of implementation of free legal aid are considered from the standpoint of the various jurisprudence (constitutional, criminal, civil, financial law, legal theory).

The system approach focuses on the study of the disclosure of the integrity of the free legal aid system, its structural elements, the identification of the different relationships between them and bringing them into a single theoretical picture.

The study is based on the principle of historicism, involves the study of the formation of the system of free legal aid to the various historical stages of development of society and the state, taking into account the specific political and socio-economic conditions, and the use of positive and negative experiences to develop and improve the system of legal aid.

Methodological tools matches the specific objectives of the work.

\subsection{Stages of Study}

The study has been carried out for two years (2014 and 2015).

The first stage (2014):

1. Analysis of the scientific literature on the topic of research, domestic and foreign experience of functioning of the institute of legal aid.

2. Gathering statistical data to assess the quality and relevance of various forms of free legal aid in the Russian Federation, members of the Volga Federal District.

3. Conducting comparative analysis of the quality and relevance of provision of free legal assistance to citizens in the Legal Clinic of Chuvash State University.

4. Survey of various segments of the population on the demand and the quality of free legal aid in the territory of the RF subjects, members of the Volga Federal District.

5. Making reports at scientific conferences in order to ensure the objectivity of scientific findings obtained in the 
course of scientific discussion.

The second stage (2015):

1. Synthesis of scientific material, which allows to evaluate the positive and negative domestic and foreign historical and contemporary experience of providing free legal aid, its organizational and legal form, the sources and methods of funding.

2. The compilation of statistics, to assess the quality and relevance of various forms of free legal aid in the Russian Federation, members of the Volga Federal District.

3. Summary of results obtained empirically in the Legal Clinic of Chuvash State University for the purpose of comparing the quality and relevance of free legal aid to citizens.

4. Preparation and publication of a monograph on the financial, organizational and legal provision of free legal assistance (for example, the Volga Federal District).

This article is a summary of the results of the first year of the study.

\section{Results}

According to Art. 4 of free legal aid Law, President of the Russian Federation determines the main directions of state policy in free legal aid provision, as well as the federal executive body authorized in free legal aid provision and its competence.

The Government of the Russian Federation is involved in determining the main directions of the state policy in providing citizens with FLA, takes measures to ensure the functioning and development of the state and non-state FLA systems, provides interaction of federal executive bodies and executive bodies of subjects of the Russian Federation in this area, including other statutory powers.

The Russian Federation government Resolution of 12.12.2012 № 1293 established the Governmental Commission on the implementation of the Federal Law "On free legal aid in the Russian Federation" (hereinafter - the Government Commission). The government commission is a coordinating body established to ensure concerted actions of the federal executive bodies and executive bodies of subjects of the Russian Federation to develop and implement the free legal aid state policy, as well as functioning and development of the state and non-state free legal aid systems.

The main objectives of the Government Commission are:

a) preparation of proposals to the President of the Russian Federation and the Government of the Russian Federation on charting the free legal aid state policy, as well as improving the legislation of the Russian Federation in this area;

b) development of measures aimed at the functioning and development of the state and non-state free legal aid systems;

c) ensuring coordination of federal executive bodies and executive bodies of the subjects of the Russian Federation to develop organizational, legal, social, economic, informational and other measures taken to guarantee the right of citizens to get free legal aid;

d) development of programs, plans and other documents on developing state and non-state free legal aid systems;

e) analysis and assessment of the rights of citizens to get free legal aid;

f) other tasks stipulated by the legislation of the Russian Federation in FLA provision.

Thus, the Government Commission approved (Minutes № 3 of 19.03.2014) the draft of the National standard of activities of legal aid systems participants, which provides for federal, regional and local regulations (Description of the project activities of the participants of the national standard system of free legal aid, 2014). The National Standard is of special social significance as it develops a common approach to the free legal aid provision, securing uniform quality requirements to free legal aid, qualifications of persons who provide it, the legal office administration (state, non-state systems, legal clinics), ethical principles, forms of social partnership between participants of different systems and levels of free legal aid provision, quality control and other requirements that will enhance the level of organization and standardization of free legal aid in the Russian Federation.

Another responsibility of the Government Commission is the development of Passport of the Russian Federation subject to assess the efficiency of state and non-state free legal aid systems functioning in the Russian Federation subjects. 
The Ministry of Justice of the Russian Federation is the authorized federal executive power in free legal aid provision, whose jurisdiction is defined by Art. 11 of the Law on free legal aid and paragraphs 30.32 and 30.33 of the Regulations on the Ministry of Justice of the Russian Federation. Thus, among the powers of the Ministry of Justice is formulating the proposals on charting and implementation of free legal aid state policy, functioning and development of the free legal aid state system, as well as legal education of the population. The Ministry is involved in the development of normative legal acts of the President of the Russian Federation and the Government of the Russian Federation relating to the functioning and development of the state and non-state free legal aid systems, takes measures to ensure the functioning and development of the state free legal aid system, coordinates the activities of those who provide free legal aid and their interactions.

It is necessary to emphasize the importance of methodological support and monitoring the activities of federal executive bodies, executive bodies of subjects of the Russian Federation, state non-budgetary funds administration, local governments, as well as government legal offices and non-government free legal aid offices that provide citizens with free legal aid and promote legal education of the population. Formulating and establishing unified standards of the free legal aid quality, monitoring the observance of professional ethics and the established requirements to the quality of legal assistance by those who provide free legal aid are also of great significance.

Public administration in providing citizens with free legal aid in the Russian Federation subjects involves passing laws and other normative legal acts of the Russian Federation establishing additional safeguards for the citizens to realize their right to get free legal aid: expanding the list of categories of citizens entitled to receive it, the list of cases when a person is entitled to get free legal aid, determining the procedure of free legal aid provision in cases of emergency for citizens who find themselves in difficult situations.

Thus, the normative legal acts of the Volga Federal District of the Russian Federation determine additional categories of entities eligible for free legal aid (Additional guarantees the right of citizens to obtain free legal aid in the Russian Federation as of 2013, 2014):

pregnant women and women with children under the age of three years - on issues related to reinstatement in work, denial of employment, recovery of wages, and payment of benefits;

former underage prisoners of concentration camps, ghettos and other places of detention, created by the Nazis and their allies during World War II;

widows of the dead (deceased) war veterans;

combat veterans;

citizens who had the status of orphans and children left without parental care, including orphans and children left without parental care under the age of 28 years;

citizens awarded "Honorary Donor of Russia", "Honorary donor of the USSR";

non-working pensioners, whose pensions are assigned in accordance with the Federal Law of 17.12.2001 №173-FZ "On Labor Pensions in the Russian Federation" dated 15.12.2001 № 166-FZ "On State Pensions in the Russian Federation";

citizens, who were declared disabled (group III) in accordance with the prescribed procedure, and who do not reside in institutions of social services;

citizens who are guardians charged with the guidance of minor children;

persons who are released from prison, within two months from the date of release - on employment issues;

rehabilitated persons and persons recognized as victims of political repression;

parents of children under the age of 14 years (disabled child - up to 18 years) in single-parent families;

parents, who have three or more minor children (including adopted), and others.

There are other cases when citizens are entitled to free legal aid, in particular (Additional guarantees the right of citizens to obtain free legal aid in the Russian Federation as of 2013, 2014), in the Orenburg region the government legal office and lawyers represent people's interests in courts, state and municipal authorities, and other organizations if they are plaintiffs in legal cases of Consumer Protection (in public services provision); the refusal of the employer to conclude an employment contract, breach of warranty, set by the Labor Code of the Russian Federation, reinstatement, recovery of wages, including backpay for forced absence, compensation for moral damage caused by unlawful actions (inaction) of the employer. In the Penza region free legal aid is also provided to protect the rights and interests of children, in the Ulyanovsk region certain categories of citizens are 
entitled to free legal aid on all matters not related to business.

Thus, given that the free legal aid Act sets certain categories of citizens eligible for free legal aid, the subjects of the Russian Federation are granted the authority to extend this list and cases, when citizens are entitled to free legal aid, which enhances the degree of social protection of citizens. It should be noted that the number of regions exercising these powers increases, which can be considered a positive trend.

Implementing the functions of public administration, the subject of the Russian Federation determines the executive authority of the subject of the Russian Federation with legal power to provide free legal aid and a list of executive bodies of the Russian Federation subject, their subordinate agencies and other organizations within the free legal aid state system on the territory of the Russian Federation subject. The main task of the authorized body is to organize and coordinate the activities of the free legal aid state system members on the territory of the Russian Federation subject, in particular, to define major participants of the free legal aid state system, to establish public law office and (or) bring in lawyers. In the majority of subjects of the Russian Federation these bodies are represented by the Government of the Russian Federation subject, regional social protection authorities or regional Department of Justice.

Under the free legal aid act local authorities may be vested with certain powers to guarantee the rights of citizens to free legal aid. Local governments may issue municipal legal acts establishing additional guarantees for citizens' rights to free legal aid, participate in establishing municipal law offices and provide citizens with all kinds of free legal aid according to the free legal aid Law.

Local governments actively began to implement such powers. According to the monitoring, local authorities carry out the provision of free legal assistance, including representation of citizens' interests in courts and other bodies in 54 subjects of the Russian Federation (Analytical Review of the monitoring activities in the sphere of Russian citizens free legal aid for 2013, 2014).

Local authorities use different ways of providing free legal aid. For example, a municipal legal office was established in Krasnodar (the decision of the municipality Krasnodar from 24.05.2012 № 4007); primary legal advice service was established In Yaroslavl (public office department "Institute of Strategic Initiatives").

Legal acts of a number of municipalities provide additional guarantees of the rights of citizens to free legal aid on the territories of municipalities. Local government bodies make decisions aimed at improving the legal literacy and legal awareness of citizens.

\section{Discussions}

The theoretical basis of the study were the works of prominent Russian lawyers - theoreticians and practitioners in the field of theory of law, constitutional, administrative and other branches of law. Their works do not specifically address the theme chosen for the study, but they are dedicated to the analysis of the legal nature of the constitutional rights and freedoms of man and citizen, the foundations of the legal status of the person and other theoretical issues. Selected Issues of realization of the constitutional right to qualified legal assistance are devoted to the works of the following authors: Alieskerov M. A. (2008), N. V. Albrant (2004), N. S. Amelkov (2014), L. N. Bardeen (2014), V. N. Belik (2006), O. N. Bondar (2008), V. K. Botnev (2013), I. M. Dolgov (2013), A. P. Zrelov (2005), V. S. Kashkovsky (2009), N. M. Kipnis (2006), V. V. Konin (2013), E. S. Lyubovenko (2008), A. G. Manafov (2002), P. G. Melnichenko (2001), N. R. Muhudinova (2012), V. Y. Panchenko (2012), A. S. Pleten (2008), E. I. Pyatin (2013), G. A. Smagin (2003), A. Taran (2008), E. G. Tarlo (1999), P. V. Fadeev (2012), I. G. Chernyakov (2007), E. S. Shugrina (2013), O. G. Yatkevich (2014) and others. However, comprehensive studies of the constitutional right to free legal aid, including issues of the state governance system of free legal aid have not yet been carried out.

\section{Conclusion}

Thus, the current system of public administration in providing free legal aid contributes to solving its main tasks, creates conditions for exercising the rights and freedoms of citizens, as well as protection of their legitimate interests, increases the level of social protection, and ensures their access to justice.

However, we can determine the future direction of its perfection:

improving the quality of the interaction between different authorities within the public administration in order to avoid the bureaucratization of free legal aid procedures;

enhancing the mobility of free legal aid state system members that will help the citizens of the Russian Federation living in remote areas exercise their constitutional right;

improving the quality of free legal aid and expanding the list of services provided thereunder; 
involving local authorities in providing free legal aid as a way of implementing the principle of free access and personal approach of free legal aid provision.

It seems that these activities aimed at improving the institution of free legal aid in the Russian Federation, will enhance the constitutional guarantees effectiveness and increase public confidence in the government and its institutions.

\section{Recommendations}

The article may be useful in a practical way for government agencies, local authorities, representatives of the legal community and other participants in the system of free legal aid, as well as for further research concerning the provision of free legal assistance in accordance with national and international experience.

\section{Acknowledgments}

The publication was prepared within the framework of research project № 14-13-21002, supported by the Russian Humanitarian Science Foundation)

\section{References}

Albrant, N. V. (2004). The constitutional right to receive legal aid in the Russian Federation. PhD Thesis. Chelyabinsk State University. Chelyabinsk, 26.

Alexandrov, A.Y. (2014). Organizational and legal problems of funding lawyers and other entities that provide free legal assistance to citizens in the framework of the state system of free legal assistance (for example, the Volga Federal District). Modern scientific thought, 5, 162-168.

Alieskerov, M. A. (2008). The right to fair judicial protection in courts of first and appellate courts in civil proceedings. Journal of Russian law, 9, 84-88.

Amelko, N. S. (2014). Provision of qualified legal aid applicants and witnesses in criminal proceedings. $\mathrm{PhD}$ Thesis. O.E. Kutafin Moscow State Law University. Moscow, 172.

Bardeen, L. N. (2014). The legal framework to support non-state legal aid system. Lawyer, 9.

Belik, V. N. (2006). State protection: the right and duty. Criminal proceedings, 2, 22-25.

Bondar, O. N. (2008). Qualified legal aid - the constitutional guarantee of judicial protection of the rights and freedoms of man and citizen in the Russian Federation. $\mathrm{PhD}$ Thesis. South Federal University. Rostov-on-Don.

Botnev, V. K. (2013). Qualified legal aid as a constitutional and legal safeguards to protect the rights and freedoms of man and citizen. $\mathrm{PhD}$ Thesis. Russian Academy of National Economy and Public Administration under the President of the Russian Federation. Moscow.

Chernyakov, I. G. (2007). The implementation of the constitutional right to qualified legal assistance: Problems and Prospects. $\mathrm{PhD}$ Thesis. Chelyabinsk State University. Chelyabinsk.

Dolgov, I. M. (2013). Problems of realization of citizens' right to qualified legal assistance in administrative proceedings. PhD Thesis. O.E. Kutafin Moscow State Law University. Moscow, 220.

Fadeev, P. V. (2012). Gaps in the legislation on qualified legal assistance. Laws of Russia: experience, analysis, and practice, 12, 89-96.

Ivanova, O. A. (2014). Historical and legal aspects of the institution of free legal assistance in foreign countries (since the formation of the ancient to modern times). Bulletin of Chuvash University, 3, 279-282.

Kashkovsky, V. S. (n. d.). Legal aid as a legal category and the socio-legal phenomenon: theory and practice. $\mathrm{PhD}$ Thesis. Tambov State University. Tambov.

Kipnis, N. M. (2006). Corporate independence of the legal profession as a guarantee of citizens' constitutional right to qualified legal assistance. Advocacy. State. Society. Collected materials of All-Russian scientific-practical conferences, 2004 - 2005. Moscow.

Konin, V. V. (2013). The right to qualified legal assistance and its availability: some theoretical questions. Advocate, 6, 9-16.

Lyubovenko, E. S. (2008). The constitutional right to qualified legal counsel and the mechanism of guarantee (Russian and foreign experience). PhD Thesis. Lomonosov Moscow State University. Moscow.

Manafov, A. G. (2002). The reform of the legal profession as the main institution providing qualified legal assistance. The right to life. Independent legal journal, 47, 103-126. 
Melnichenko, R. G. (2001). The constitutional right to legal assistance. PhD Thesis. Volgograd Academy of Public Administration. Volgograd, 201.

Muhudinova, N. R. (2012). The constitutional right to qualified legal assistance to guarantee the rights of members of the Russian criminal justice system. Socio-Political Sciences, 1,119-121.

Panchenko, V. Y. (2012). The approaches to the concept of "legal advice" in the modern domestic jurisprudence. Russian Law Journal, 1, 77-81.

Pleten, A. S. (2008). The constitutional right to free legal aid and the mechanism of its realization in modern Russia. PhD Thesis. O.E. Kutafin Moscow State Law Academy. Moscow, 175.

Pyatin, E. I. (2013). Legal regulation of relations on legal aid (service) in Russia. Education and Law, 3-4, 66-74.

Russian Federation. The Ministry of Justice of the Russian Federation. (2014). Description of the project activities of the participants of the national standard system of free legal aid. Retrieved from http://minjust.ru/ru/node/105812

Russian Federation. The Ministry of Justice of the Russian Federation. (2014). Additional guarantees the right of citizens to obtain free legal aid in the Russian Federation as of 2013. Retrieved from http://minjust.ru/ru/node/105812

Russian Federation. The Ministry of Justice of the Russian Federation. (2014). Analytical Review of the monitoring activities in the sphere of Russian citizens free legal aid for 2013. Retrieved from http://minjust.ru/ru/node/105812

Shugrina, E. G. (2013). The possibility and the need to establish legal clinics in Russia. Legal education in Russia and abroad: problems and prospects: Interuniversity collection of abstracts of scientific and practical conference. Kursk. P. 96-106.

Smagin, G. A. (2003). Constitutional and legal issues of providing qualified legal assistance to the Russian Federation. PhD Thesis. Moscow University for the Humanities. Moscow, 163.

Taran, A. S. (2008). Lawyer in conflict with the judge. Criminal law, 1, 113-117.

Tarlo, E. G. (1999). The constitutional right to legal assistance. State of Law. Legal popular science magazine, 1 , 32-49.

Vereshchak, S. B. (2014). Non-governmental legal aid system: problems of functioning and the main directions of development. Bulletin of Chuvash University, 3, 257-261.

Yatkevich, O. G. (2014). The level of elaboration of the concept of "the realization of the human right to qualified legal assistance." Lawyer, 4, 4-8.

Zrelov, A. P. (2005). Questions pay lawyers involved in the civil proceedings for the appointment of court. Law and economics, 9, 82-83.

\section{Copyrights}

Copyright for this article is retained by the author(s), with first publication rights granted to the journal.

This is an open-access article distributed under the terms and conditions of the Creative Commons Attribution license (http://creativecommons.org/licenses/by/3.0/). 